\title{
INTENSI BERWIRAUSAHA DI BIDANG PERTANIAN DENGAN PENDEKATAN PLANNED BEHAVIOR THEORY
}

\author{
Anissa Mayang ${ }^{\left.1^{*}\right)}$, Fajer Rifa'i ${ }^{2)}$ and Khairul lkhwan ${ }^{3)}$ \\ 1,2,3)Dosen Universitas Tidar \\ mayang.anissa2@gmail.com
}

\begin{abstract}
ABSTRAK
Angka pengangguran di Indonesia menunjukkan peningkatan, terutama pada kaum terpelajar atau calon lulusan. Hal ini disebabkan oleh kurangnya minat para calon lulusan khususnya untuk berwirausaha pada sector pertanian. Penelitian ini bertujuan untuk menganalisis factor - factor yang mempengaruhi niat mahasiswa pertanian menjadi wirausaha pertanian melalui pendekatan theory of planned behavior. Metode penelitian menggunakan analisis deskriptif dan analisis regresi dengan menggunakan sampel sebanyak 120 responden mahasiswa Fakultas Pertanian Universitas Tidar. Hasil penelitian terdapat pengaruh gabungan yaitu variabilitas intensi berwirausaha yang mampu dijelaskan oleh variabilitas pengaruh sikap, norma subjektif, kontrol perilaku dan karakteristik pendidikan. Hasil menunjukkan bahwa sikap, norma subjektif dan kontrol perilaku secara parsial memiliki pengaruh positif dan signifikan terhadap intensi berwirausaha. Karakteristik pendidikan secara parsial tidak memiliki pengaruh terhadap intensi berwirausaha.
\end{abstract}

Kata Kuncu: Wirausah,; Theory Planned Behavior, Pertanian

\section{PENDAHULUAN}

Tingginya tingkat pengangguran di Indonesia ini merupakan suatu masalah besar. Lebih maraknya tingkat pengangguran saat ini adalah dari kaum terpelajar yang seharusnya menjadi aset masa depan bangsa. Berdasarkan Badan Pusat Statistik (BPS, 2019) mencatat jumlah pengangguran berdasarkan angkatan kerja pada Agustus 2019 mencapai 7,05 juta orang. Jumlah ini bertambah sekitar 50 ribu orang atau naik $0,7 \%$ dari periode yang sama tahun lalu. Jika dibandingkan dengan Februari 2019 yang hanya 6,82 juta orang, peningkatan pengangguran Agustus 2019 mencapai $3,4 \%$. Melemahnya perekonomian Indonesia berakibat pada meningkatnya tingkat pengangguran di Indonesia. Sebuah negara baru akan makmur kalau sedikitnya $2 \%$ dari penduduknya menjadi entrepreneur (Ciputra, 2011). Jumlah wirausaha di Indonesia masih tertinggal, khususnya terhadap negara tetangga, Malaysia, Singapura dan Thailand.

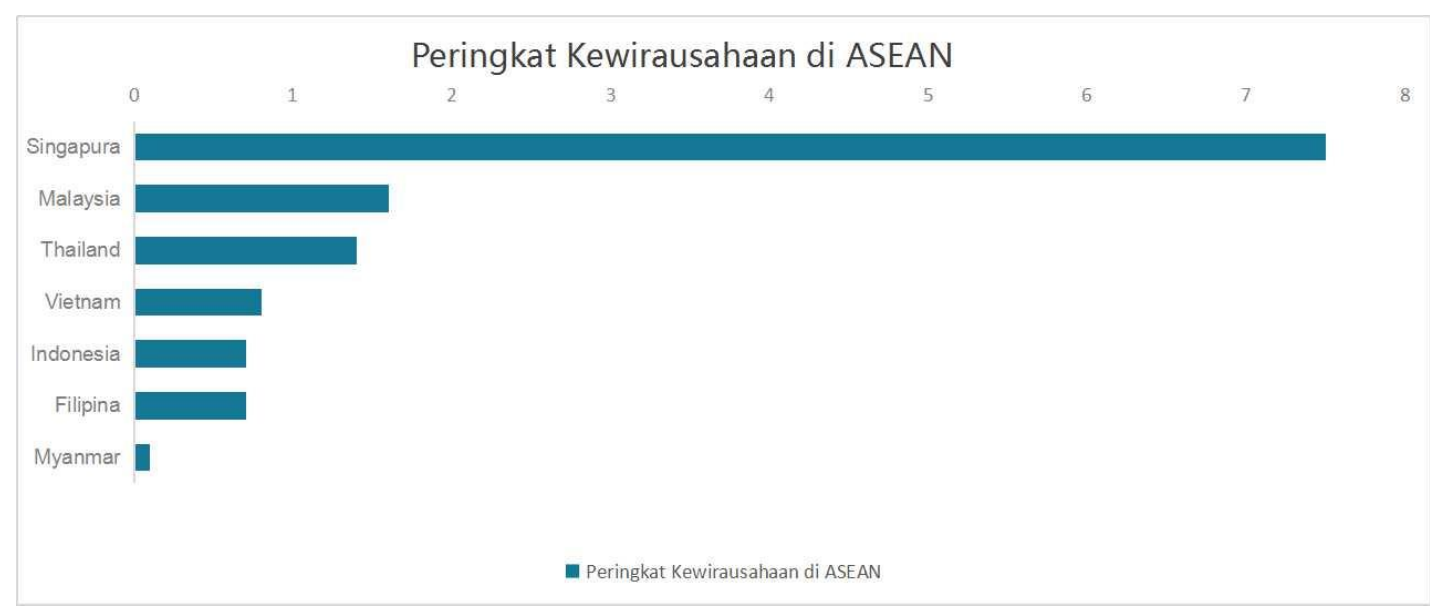

Gambar 1. Peringkat Kewirausahaan di ASEAN

Sumber: U.S. News \& World Report 2019 
Menurut laporan US News and World Report (2019) Best Countries, Indonesia dan Filipina menempati peringkat kedua terendah dalam dimensi kewirausahaan pada 2018 (lihat Gambar 2). Skor yang diperoleh Indonesia dan Filipina sebesar 0,7 dari skala 10. Semakin tinggi skor yang diperoleh, semakin tinggi pula iklim kewirausahaan dalam suatu negara. Di tingkat dunia, Indonesia berada di peringkat ke-50 dari 80 negara yang disurvei. Rendahnya peringkat kewirausahaan Indonesia disebabkan rendahnya skor pada semua indikator, yaitu di bawah 2 dari skala 10. Ada beberapa indikator yang mendapatkan skor rendah, yakni kerangka hukum yang baik dan keahlian teknologi dengan skor masing-masing sebesar 0,3 dan 0,5. Sementara itu, skor tertinggi yang diperoleh Indonesia adalah 1,8 untuk indikator terhubungnya Indonesia ke seluruh dunia. Survei ini dilakukan terhadap 21 ribu responden dari lima kawasan. Kawasan tersebut adalah Amerika, Asia, Eropa, Timur Tengah, dan Afrika yang tersebar di 80 negara dunia, sedangkan di ASEAN sebanyak tujuh negara.

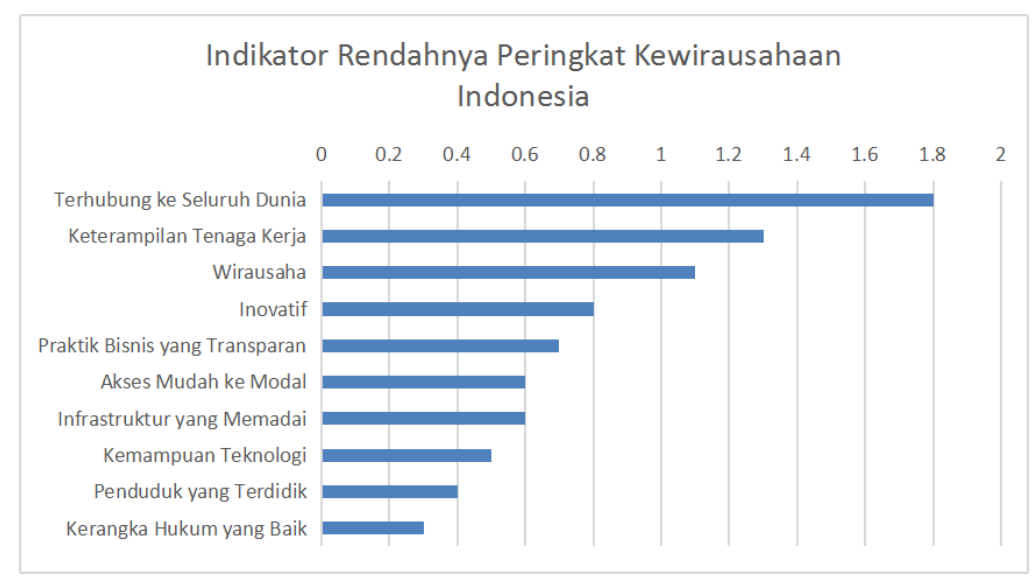

\section{Gambar 2. Indikator peringkat kewirausahaan}

Sumber: U.S. News \& World Report 2019

Skor yang didapatkan Indonesia dalam kewirausahaan sebesar 0,7 dari skala 0-10. Nilai mendekati 0 mengindikasikan semakin buruk dimensi kewirausahaan suatu negara dan sebaliknya. Rendahnya peringkat Indonesia disebabkan indikator yang membentuk dimensi kewirausahaan memiliki skor di bawah 2 dari skala 0-10. Adapun skor terendah terdapat pada indikator kerangka hukum dan penduduk yang terdidik dengan masing-masing skor 0,3 dan 0,4. Kemampuan teknologi juga menjadi hambatan bagi Indonesia untuk meningkatkan iklim kewirausahaan. Selain itu, infrastruktur yang memadai dan akses ke modal juga menjadi perhatian karena berada di peringkat empat terendah dengan skor 0,6 poin.

Data dari Marketing Research Indonesia (MRI) menunjukan, "Jumlah wirausaha Indonesia sebanyak $1,65 \%$ dari total jumlah penduduk 253,61 juta jiwa, sedangkan Malaysia, Singapura dan Thailand lebih tinggi jumlah wirausahanya, sebesar $5 \%, 7 \%$ dan $3 \%$ dari total jumlah penduduk tiap negara" (MRI, 2015). hal ini dikarenakan banyak UKM di Indonesia yang belum mendapatkan dukungan dari pemerintah maupun swasta untuk mengembangkan bisnisnya. oleh karena itu, enterpreneurship perlu didorong karena memiliki potensi yang besar untuk membantu mendongkrak perekonomian di indonesia.

Kementerian Perindustrian menargetkan 20.000 wirausaha untuk membentuk wirausaha baru (Saraswati, 2018). Upaya untuk mencapai target tersebut dengan memberikan bekal terhadap calon pengusaha baru dengan sejumlah keterampilan dasar. Pemerintah memberikan fasilitas pendampingan dan pelatihan yang mendukung dalam pencapaian target tersebut. Selain itu pemerintah juga memberikan bantuan dalam urusan perizinan sehingga dapat mempermudah dalam mendapatkan perizinan usaha. Pemerintah juga memotivasi kaum muda untuk menjadi wirausahawan daripada menjadi pencari kerja dengan upaya tersebut diharapkan wirausahawan di indonesia meningkat dan mampu mendorong indonesia menuju negara maju. 


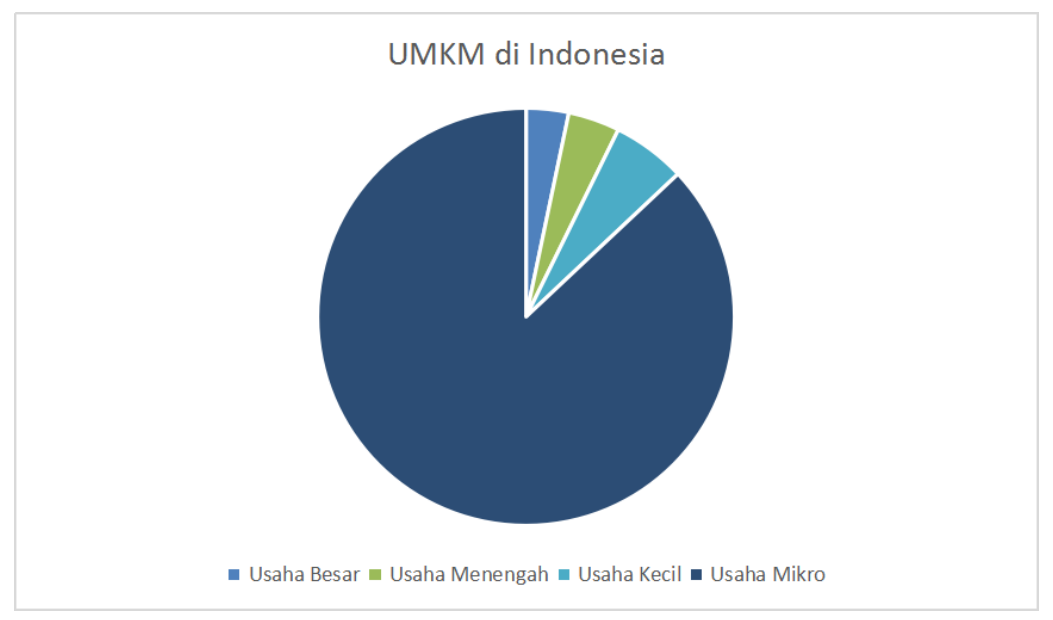

Gambar 3. Persentase UMKM di Indonesia

\section{Sumber : Bank Indonesia, 2016}

Usaha Mikro Kecil dan Menengah (UMKM) memegang peranan penting dalam struktur perekonomian Indonesia. Berdasarkan data Bank Indonesia seperti diperlihatkan pada Gambar 3, pada 2016 sektor UMKM mendominasi 99,9 persen unit bisnis di Indonesia dan mampu menyerap hampir 97 persen tenaga kerja Indonesia. Dari angka tersebut, jenis usaha mikro paling banyak menyerap tenaga kerja hingga 87 persen. Sementara usaha besar hanya dapat menyerap 3,3 persen. Pemerintah berusaha mendorong pengembangan UMKM melalui Kemenperin dengan mengembangkan program platform e-commerce yang bertajuk e-Smart IKM. Pengembangan ini sebagai salah satu upaya strategis pemerintah untuk membangun sistem database IKM (industri kecil menengah) yang diintegrasikan melalui beberapa marketplace yang sudah ada di Indonesia untuk mendorong pemasaran IKM. Program lain yang dikembangkan pemerintah melalui OJK yaitu program laku pandai (layanan keuangan tanpa kantor dalam rangka keuangan inklusif). Program laku pandai ini untuk menyediakan layanan perbankan atau keuangan lainnya melalui kerja sama antar pihak lain (agen bank), dan didukung dengan penggunaan sarana teknologi informasi.

Perguruan Tinggi juga mendukung pemerintah dalam meningkatkan wirausaha. Dukungan tersebut direalisasikan dengan membuat berbagai program. Program yang dijalankan salah satunya yaitu program peningkatan kompetensi tenaga kerja dan produktivitas bagi mahasiswa. Program ini mendorong mahasiswa untuk dapat memberikan gagasan dan kontribusi serta mempersiapkan diri untuk membuka lapangan pekerjaan baru. Pemerintah sudah menjalin kerja sama dengan berbagai perguruan tinggi di indonesia serta sudah membuka 208 balai latihan kerja (Ristekdikti 2012).

Peran internal dari perguruan tinggi juga diperlukan untuk menumbuhkan jiwa dan semangat entrepreneur dikalangan akademisi. Terdapat usaha untuk menyerukan kewirausahaan di beberapa perguruan tinggi antara lain pendirian pusat kewirausahaan kampus seperti Entrepreneruship Center (BEC) di BSI, Pusat Inkubator Bisnis ITB, Koperasi kesejahteraan Mahasiswa (KOKESMA) ITB, Community Business and Entrepreneurship Development (CDED) di STMB Telkom, Community Entrepreneur Program (CEP) UGM (Ristekdikti 2017).

Jumlah wirausahawan baru dibidang pertanian seharusnya ikut meningkat seiring usaha pemerintah meningkatkan jumlah wirausahawan. Penambahan wirausahawan pertanian menjadi krusial karena kebutuhan pangan Indonesia terus meningkat dari tahun ke tahun. peningkatan jumlah wirausahawan pertanian harus menjadi konsen pemerintah karena regenerasi wirausahawan pertanian tergolong sulit. Selain itu, pentingnya regenerasi petani karena pertanian masih dipegang oleh generasi baby boomer yaitu generasi yang lahir sekitar tahun 60-an yang dicirikan adopsi teknologi mereka yang rendah (KPPA dan BPS 2018). 


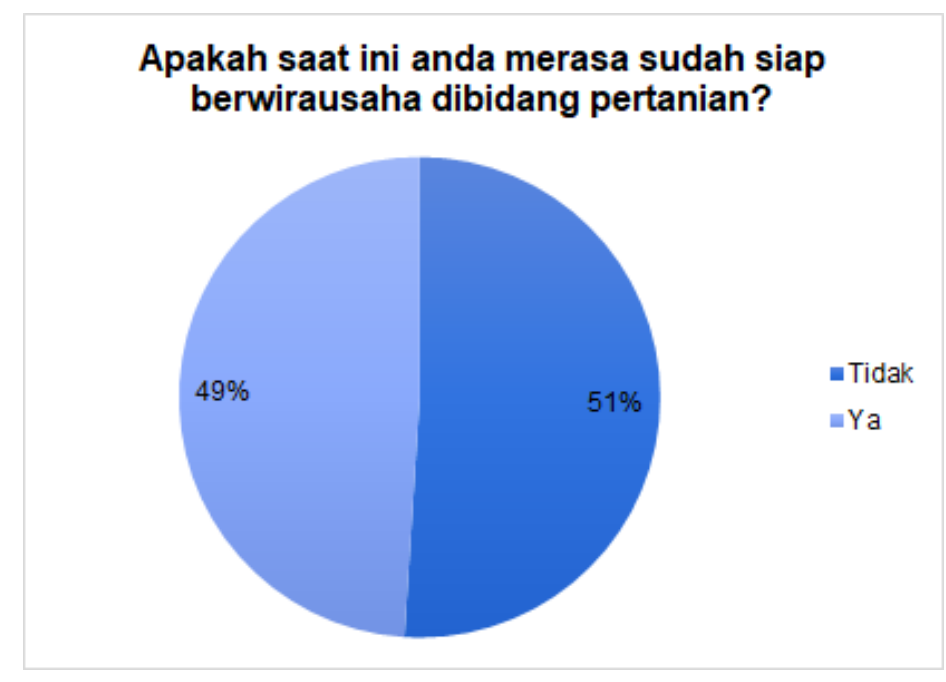

Gambar 4. Survei kesiapan berwirausaha mahasiswa Fakultas Pertanian

Sumber: Data diolah penulis 2020

Peneliti melakukan survei awal terhadap kesiapan berwirausaha terhadap 98 mahasiswa fakultas pertanian di bidang usaha pertanian. survei menunjukkan mahasiswa yang tidak siap lebih besar dibanding mahasiswa yang siap berwirausaha. Sebanyak 51\% mahasiswa menyatakan tidak siap dan $49 \%$ menyatakan siap. Padahal Universitas Tidar fokus terhadap kewirausahaan yang tergambar dalam moto Untidar yaitu: "Terdepan dalam wirausaha".

Berdasarkan survei awal tersebut menunjukkan masih adanya ketimpangan antara usaha yang dilakukan pemerintah dan universitas dalam meningkatkan wirausaha baru dengan kesiapan mahasiswa berwirausaha. oleh karena itu, perlu diteliti lebih dalam apakah yang menjadi faktor yang mempengaruhi niat berwirausaha mahasiswa fakultas pertanian. Fokus penelitian ini bertujuan mengidentifikasi pengaruh faktor sikap, norma subjektif, kontrol perilaku terhadap niat berwirausaha mahasiswa yang diadopsi dari Theory of Planned Behavior (Ajzen, 2008). Penelitian ini juga bertujuan mengidentifikasi karakteristik mahasiswa untuk menjadi wirausaha pertanian.

\section{METODE PENELITIAN}

\section{Waktu dan lokasi penelitian}

Waktu pelaksanaan penelitian dilaksanakan pada bulan Desember 2019 - Juni 2020 . Lokasi penelitian dilakukan di Universitas Tidar dengan pengambilan sampel pada mahasiswa Fakultas Pertanian.

\section{Teknik pengambilan sampel}

Teknik pengumpulan data melalui pengisian kuesioner secara digital terhadap responden. pengumpulan data menggunakan teknik simple random sampling yaitu setiap orang memiliki kesempatan yang sama dengan yang lainnya untuk dipilih menjadi anggota sampel. Responden dalam penelitian ini adalah mahasiswa aktif fakultas pertanian lintas prodi dan angkatan. Jumlah responden berjumlah 120 mahasiswa.

Data kuesioner yang dikumpulkan diukur dengan skala likert. dimulai dari satu sampai lima dengan keterangan sebagai berikut: nilai $=5$ (sangat setuju): nilai $=4$ (setuju); nilai $=3$ (netral); nilai $=2$ (tidak setuju); nilai = 1 (sangat tidak setuju). definisi operasional diturunkan menjadi bahan pertanyaan dalam kuesioner. 


\section{Metode Analisis}

Metode analisis data yang digunakan pada penelitian ini adalah analisis deskriptif dan analisis regresi. Analisis deskriptif digunakan untuk memberikan gambaran empiris dari data secara umum. Analisis regresi digunakan untuk menguji hubungan antar variabel yang akan diteliti.

Variabel independen dalam penelitian ini yaitu: sikap, norma subjektif, kontrol perilaku, dan karakteristik pendidikan sedangkan variabel dependen dalam penelitian ini yaitu: niat berwirausaha. Kerangka model penelitian disajikan pada Gambar 5 . Hipotesis yang disusun berdasarkan kerangka model penelitian yang dibangun adalah sebagai berikut :

$\mathrm{H} 1$ : sikap berpengaruh positif dan signifikan terhadap niat berwirausaha pertanian

H2 : norma subjektif berpengaruh positif dan signifikan terhadap niat berwirausaha pertanian

$\mathrm{H} 3$ : kontrol perilaku berpengaruh positif dan signifikan terhadap niat berwirausaha pertanian

H4 : karakteristik pendidikan berpengaruh positif dan signifikan terhadap niat berwirausaha pertanian

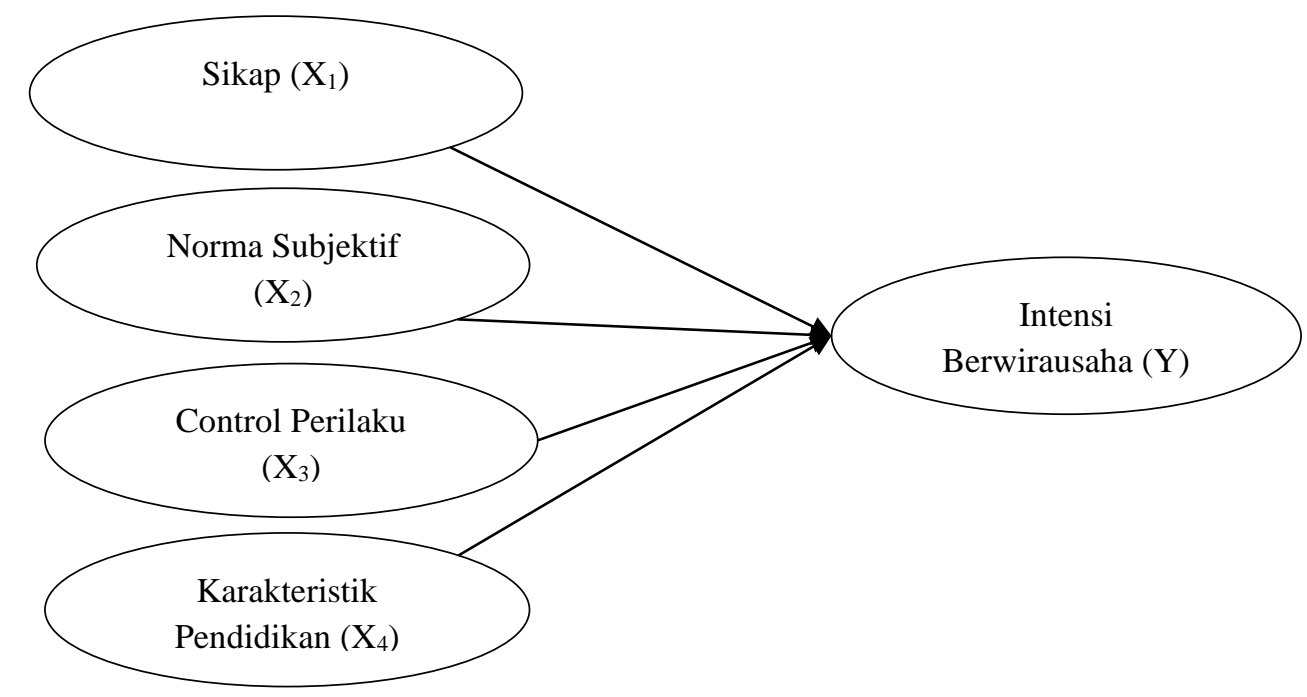

\section{Gambar 5. Model kerangka penelitian}

Defenisi operasional digunakan untuk mengukur konsep - konsep dalam penelitian ini dengan cara pengoperasionalisasian konsep dari variabel dengan cara menetapkan rincian indikator variabel yang akan digunakan dalam pengukuran.

\section{HASIL DAN PEMBAHASAN}

\section{Analisis Deskriptif}

Responden penelitian ini adalah 120 mahasiswa fakultas pertanian Universitas Tidar. Responden tersebut terdiri dari $73(60,8 \%)$ mahasiswa perempuan dan $47(39,2 \%)$ mahasiswa laki laki. sebagian responden berusia 20 tahun (26,7\%) diikuti responden yang berusia $\leq 19$ tahun $42,5 \%$ dan $\geq 21$ tahun $30,8 \%$. Dari hasil analisis deskriptif terhadap pengalaman pendidikan kewirausahaan mahasiswa yang bertujuan untuk mengetahui seberapa besar kemungkinan pengalaman pendidikan memberikan wawasan kepada mahasiswa. pengalaman pendidikan dibagi menjadi dua, yaitu formal dan informal. pendidikan formal kewirausahaan didapat melalui kuliah atau pembelajaran, sedangkan pendidikan informal didapatkan dari pelatihan, workshop dan seminar kewirausahaan. dapat dilihat pada tabel bahwa mayoritas mahasiswa pertanian telah mendapatkan pendidikan formal kewirausahaan sebanyak 0 - 5 kali dengan persentase $96,7 \%$. sedangkan untuk pendidikan informalnya sebagian besar mahasiswa mendapatkan sebanyak 0 - 5 kali dengan persentase $95,8 \%$. 
Tabel 2. Karakteristik Pendidikan

\begin{tabular}{lcc}
\hline \multicolumn{1}{c}{ Karakteristik Individu } & \multicolumn{2}{c}{ Kategori } \\
\hline Pengalaman Budidaya Pertanian & Pernah & Belum \\
& $96(80 \%)$ & $24(20 \%)$ \\
Jumlah Pendidikan Kewirausahan Formal & $0-5$ & $>5$ \\
Jumlah Pendidikan Kewirausahaan Informal & $116(96,7 \%)$ & $4(3,3 \%)$ \\
& $0-5$ & $>5$ \\
& $115(95,8 \%)$ & $5(4 \%)$ \\
\hline
\end{tabular}

sumber : data diolah penulis (2020)

Hasil analisis deskriptif terhadap Indeks Prestasi Kumulatif (IPK) pada gambar 6 menunjukkan bahwa sebagian besar mahasiswa fakultas Pertanian memiliki IPK $>3,5$ sebesar $16,7 \%$ dan $<3,5$ sebesar $83,3 \%$.

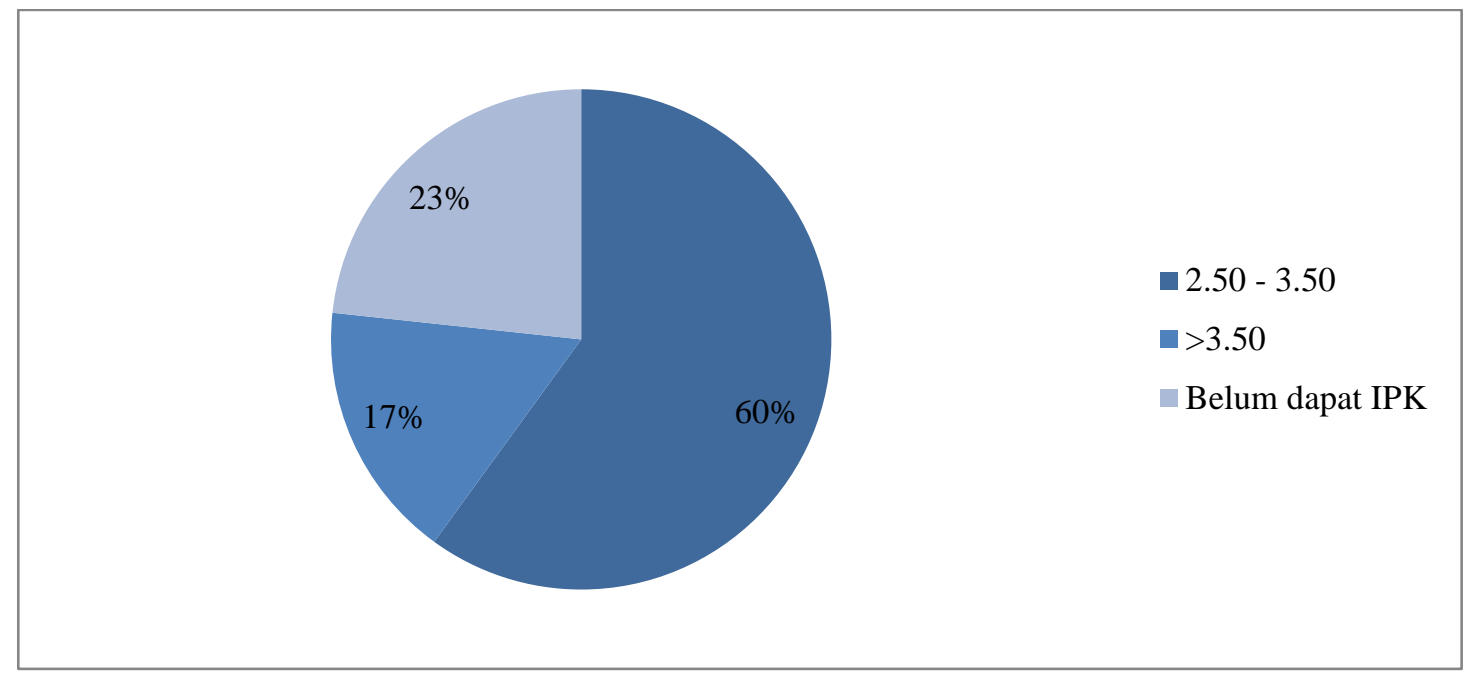

Gambar 6. Indeks Prestasi Kumulatif Mahasiswa

Sebanyak 93,3 \% mahasiswa menganggap IPK bukan menjadi faktor penjamin kesiapan mahasiswa dalam berwirausaha. berasal dari tekat, niat, bekerja keras dan mental menjadi faktor kesiapan mahasiswa dalam berwirausaha. Beberapa responden menggambarkannya sebagai berikut :

a. "belum tentu memiliki IPK yang tinggi memiliki skill yang tinggi"

b. "Siap atau tidaknya wirausahawan tergantung pada tekat modal dan penguasaan pada bidang usaha yg akan digeluti"

c. "Karena dunia berwirausaha bukan melulu soal IPK saja melainkan siap tidak untuk merasakan kegagalan"

d. "Karena IPK tidak menjadi jaminan siap berwirausaha namun ketekunan, ulet dan kerja keras pantang menyerah yang menjadi kekuatan"

e. "Setiap orang yang sudah bernalar berhak untuk berwirausaha karena menjadi seorang wirausaha yang sukses nilai dan materi bukan yang utama"

Sehingga dapat disimpulkan bahwa IPK bukan jaminan keberhasilan untuk melakukan wirausaha. dimulai dari skill, tekat, niat dan bekerja keras yang akan mampu mendorong keberhasilan dalam wirausaha. 


\section{Uji validitas dan reliabilitas}

Uji validitas digunakan untuk mengukur keabsahan setiap butir-butir pertanyaan. Uji validitas sebagai alat ukur yang tepat dalam mengukur apa yang hendak kita ukur menggunakan pendekatan korelasi item-total dikoreksi (corrected item-total correlation). Dapat dilihat pada Tabel 3 yang menunjukkan bahwa nilai $r$ hitung tiap pertanyaan penelitian ternyata lebih besar dari $r$ kritis sebesar 0,20 . Dapat dilihat pada tabel tersebut hasil menunjukkan bahwa setiap pertanyaan penelitian yang digunakan dalam penelitian ini benar-benar merepresentasikan apa yang akan diukur.

Tabel 3. Uji Validitas dan Uji Reliabilitas

\begin{tabular}{|c|c|c|}
\hline Variabel & $\begin{array}{l}\text { Validitas } \\
\text { (rhitung) }\end{array}$ & $\begin{array}{l}\text { Cronbach's } \\
\text { Alpha }\end{array}$ \\
\hline \multicolumn{3}{|l|}{ Sikap } \\
\hline Wirausaha pertanian adalah pekerjaan yang mulia & 0.760 & \multirow{4}{*}{0.746} \\
\hline Wirausaha pertanian di era digital itu menguntungkan & 0.777 & \\
\hline Penting untuk memiliki pekerjaan yang mulia & 0.730 & \\
\hline Penting untuk memiliki pekerjaan yang menguntungkan di era digital & 0.753 & \\
\hline \multicolumn{3}{|l|}{ Norma subjektif } \\
\hline Teman-teman mendorong berwirausaha pertanian & 0.868 & 0.855 \\
\hline Keluarga mendorong berwirausaha pertanian & 0.838 & \\
\hline Saya ingin mengikuti saran teman untuk menjadi wirausaha & 0.864 & \\
\hline Saya ingin mengikuti saran yang dianjurkan keluarga & 0.766 & \\
\hline \multicolumn{3}{|l|}{ Kontrol perilaku } \\
\hline Saya memiliki pengetahuan dan kemampuan untuk berwirausaha & 0.712 & 0.820 \\
\hline Kesempatan untuk menjadi wirausaha pertanian terbuka luas & 0.804 & \\
\hline $\begin{array}{l}\text { Memiliki pengetahuan dan kemampuan mendorong saya untuk } \\
\text { menjadi wirausaha pertanian }\end{array}$ & 0.863 & \\
\hline $\begin{array}{l}\text { Kesempatan yang terbuka luas membuat saya ingin menjadi } \\
\text { wirausaha pertanian }\end{array}$ & 0.844 & \\
\hline \multicolumn{3}{|l|}{ Intensi berwirausaha } \\
\hline $\begin{array}{l}\text { Saya ingin mencoba menjadi wirausahawan pertanian saat masih } \\
\text { menjadi mahasiswa }\end{array}$ & 0.886 & 0.841 \\
\hline $\begin{array}{l}\text { Saya berencana untuk berwirausaha di bidang pertanian sebagai } \\
\text { pekerjaan utama / pekerjaan sampingan }\end{array}$ & 0.868 & \\
\hline Saya berencana untuk menjadi wirausahawan pertanian professional & 0.866 & \\
\hline
\end{tabular}

Sumber: Data diolah penulis (2020)

Suatu kuesioner pertanyaan dapat digunakan dalam memperoleh data primer dinyatakan valid jika jawaban responden konsisten (Ghozali 2016). Uji yang digunakan dalam melihat reliabilitas responden menggunakan uji Cronbach Alpha. Pada Tabel 3 dapat dilihat bahwa hasil uji reliabilitas 
terhadap variabel sikap, norma subjektif, kontrol perilaku dan intensi berwirausaha menunjukkan nilai Cronbach alpha setiap variabel lebih besar dari 0,600. Nilai Cronbach alpha menunjukkan semua variabel yang diteliti memenuhi unsur reliabilitas (Sekaran 2000).

\section{Uji Normalitas}

Uji Normalitas menggunakan Kolmogorov-Smirnov menyimpulkan bahwa tidak terdapat masalah mengenai normalias dari distribusi residual. Pernyatan ini dibuktikan dengan nilai Asymp. Sig (2tailed) 0.200 lebih tinggi dari asumsi tingkat signifikansi 5\%. Hasil Uji Normalias Residual terdapat pada tabel 4 berikut:

Tabel 4. Uji Normalitas

$\begin{array}{ll}\text { Nama Uji Asymp. Sig (2-tailed) } & \text { Asta }\end{array}$

Kolmogorov-Smirnov $\quad 0.200$

Sumber: Data diolah penulis (2020)

\section{Uji Multikolinearitas}

Nilai Variance Inflation Factor (VIF) masing-masing variabel independen yang diperoleh melalui Uji Multikolinearitas sebesar 1.367, 1.581, 1.753 dan 1.100. Nilai Variance Inflation Factor (VIF) kurang dari 10 yang berarti tidak ada multikolinearitas antar variabel independen dalam model regresi. Hasi uji multikolinearitas dapat ditunjukkan pada table 5 berikut:

\section{Tabel 5. Uji Multikolinearitas}

\begin{tabular}{ll}
\hline Variabel Independen (X) & Nilai Variance Inflation Factor (VIF) \\
\hline Sikap (X1) & 1.367 \\
Norma Subjektif (X2) & 1.581 \\
Kontrol Perilaku (X3) & 1.753 \\
Karakteristik Pendidikan (X4) & 1.100 \\
\hline
\end{tabular}

Sumber: Data diolah penulis (2020)

\section{Uji Heteroskedastisitas}

Uji Heteroskedastisitas menggunakan Uji Glejser menyimpulkan bahwa terdapat masalah heteroskedastisitas dalam model regresi. Pernyataan tersebut dibuktikan dengan nilai probabilitas variabel kontrol perilaku yang diperoleh sebesar 0.008 atau lebih rendah dari asumsi tingkat signifikansi sebesar 0.05. Hasil Uji Heteroskedastisitas penelitian ini terangkum melalui tabel. Masalah heteroskedastisitas pada penelitian ini menyebabkan model regresi menjadi tidak valid. Model regresi dilakukan mekanisme robust standard error. Mekanisme robust standard error digunakan untuk mensetel masalah heteroskedastisitas sehingga penarikan kesimpulan secara statistisk dalam penelitian ini tetap dapat dilakukan. Hasil estimasi final model regresi penelitian ini terangkum melalui Tabel 7 berikut: 


\begin{tabular}{|c|c|c|c|c|c|c|}
\hline & & \multicolumn{2}{|c|}{ Unstandardized Coefficients } & \multirow{2}{*}{$\begin{array}{c}\text { Standardized } \\
\text { Coefficients }\end{array}$} & \multirow[b]{2}{*}{$\mathrm{T}$} & \multirow[b]{2}{*}{ Sig. } \\
\hline \multicolumn{2}{|c|}{ Model } & B & Std. Error & & & \\
\hline \multirow[t]{5}{*}{1} & (Constant) & 4.108 & .875 & & 4.694 & .000 \\
\hline & Sikap & -.050 & .055 & -.092 & -.915 & .362 \\
\hline & Norma subjektif & .006 & .035 & .018 & .168 & .867 \\
\hline & Kontrol perilaku & -.118 & .044 & -.309 & 2.705 & .008 \\
\hline & $\begin{array}{l}\text { Karakteristik } \\
\text { pendidikan }\end{array}$ & -.035 & .039 & -.080 & -.890 & .375 \\
\hline
\end{tabular}

a. Dependent Variable: Abs_RES

Tabel 7. Estimasi Final Model Regresi

Variabel Prediktor Koefisien Regresi Robust Standard Error thitung $P>|t|$

Penelitian

\begin{tabular}{llllll}
\hline Sikap & X1 & 0.3493 & 0.1061 & 3.2918 & $0.0013^{*}$ \\
Norma Subjektif & X2 & 0.1441 & 0.0541 & 2.6650 & $0.0088^{*}$ \\
Kontrol Perilaku & X3 & 0.3664 & 0.0852 & 4.3019 & $0.000^{*}$ \\
Karakteristik Pendidikan & X4 & -0.0876 & 0.566 & -1.5478 & 0.1244 \\
\hline F- Statistik & & $\mathbf{0 . 0 0 0}$ & & & \\
$\boldsymbol{R P}^{2}$ & & $\mathbf{0 . 5 3 4 1}$ & & & \\
\hline
\end{tabular}

Sumber: Data diolah penulis (2020)

Keterangan: * signifikan pada asumsi tingkat signifikansi $5 \%$

\section{Kelayakan Model Regresi}

Kelayakan model regresi dapat dilihat melalui nilai signifikansi Uji Statistik F. Hasil estimasi final menunjukkan bahwa nilai signifikansi yang diperoleh sebesar 0.0000 . Nilai $0.0000<0.05$ merepresentasikan bahwa model regresi dapat dikatakan layak dan tepat. Output Uji Statistik F pada penelitian ini dapat dilihat pada table 7 .

\section{Pengaruh Gabungan}

Nilai koefisien determinasi yang diperoleh melalui pengolahan data riset sebesar $53,41 \%$. Nilai tersebut menjelaskan bahwa variabilitas variabel Intensi Wirausaha mampu dijelaskan oleh variabilitas variabel sikap, norma subjektif, kontrol perilaku dan karakteristik pendidikan sebesar $53,41 \%$ sedangkan sisanya sebesar $46,59 \%$ dijelaskan oleh variabel lain.

\section{Pengaruh Parsial}

Hasil analisis regresi menggambarkan bagaimana pengaruh masing - masing variabel independen mempengaruhi variabel dependen. Dibawah akan dijelaskan bagaimana pengaruh variabel independen memiliki pengaruh masing masing variabel dependen. Hasil dari pengaruh setiap variabel dapat dilihat pada hasil regresi yang disajikan pada tabel. 


\section{Pengaruh variabel sikap terhadap intensi berwirausaha}

Hasil analisis menunjukkan bahwa variabel sikap berpengaruh positif dan signifikan terhadap intensi kewirausahaan. Nilai signifikansi sebesar $0.0013<0.05$. besarnya pengaruh variabel sikap terhadap intensi kewirausahaan mengacu pada Nilai Standardized Coefficient Beta sebesar 34.93\%.

Hasil penelitian ini menunjukkan bahwa hipotesis diterima bahwa sikap berpengaruh positif dan signifikan terhadap intensi berwirausaha. Sikap wirausaha yang meliputi: memandang bahwa seseorang wirausaha adalah orang yang berfikir inovatif, bekerja keras dan mandiri. Hal ini berarti menunjukkan bahwa semakin baik dan positif penilaian mahasiswa terhadap profesi wirausaha maka semakin tinggi niatnya untuk menjadi wirausaha. Penelitian diperkuat oleh temuan dari (Suharti, 2011) bahwa faktor - faktor sikap terbukti berpengaruh signifikan dan positif terhadap niat kewirausahaan mahasiswa.

\section{Pengaruh variabel norma subjektif terhadap intensi berwirausaha}

Hasil analisis menunjukkan variabel norma subjektif berpengaruh positif dan signifikan terhadap intensi berwirausaha. Nilai signifikansi sebesar $0.0088<0,05$. Besarnya pengaruh variabel norma subjektif terhadap intensi kewirausahaan mengacu pada Nilai Standardized Coefficient Beta sebesar $14.41 \%$.

Hasil penelitian ini menunjukkan bahwa hipotesis diterima norma subjektif berpengaruh positif dan signifikan terhadap intensi berwirausaha Mahasiswa Fakultas Pertanian Universitas Tidar. Niat untuk berwirausaha akan terbentuk apabila teman dekat, dosen maupun orang tua memberikan pengaruh positif dan dukungan terhadap niat tersebut. Hasil ini diperkuat oleh penelitian yang dilakukan (Gracia, 2010) yang meneliti Entrepreneur Intention: The role of gender, menemukan bahwa norma subjektif berpengaruh signifikan terhadap niat kewirausahaan.

\section{Pengaruh variabel kontrol perilaku terhadap intensi berwirausaha}

Hasil analisis menunjukkan variabel control perilaku berpengaruh positif dan signifikan terhadap intensi berwirausaha. Nilai signifikansi sebesar $0.0000<0.05$. besarnya pengaruh variabel control perilaku terhadap intensi kewirausahaan mengacu pada Nilai Standardized Coefficient Beta sebesar $36.64 \%$.

Hasil penelitian menunjukkan bahwa hipotesis diterima bahwa control perilaku berpengaruh positif dan signifikan terhadap intensi berwirausaha. Semakin tinggi rasa kepercayaan diri mahasiswa dalam mengelola usaha serta kematangan mental yang dimilikinya maka semakin tinggi pula niat mahasiswa untuk menjadi wirausaha. Penelitian juga diperkuat oleh temuan yang dilakukan oleh (Tjahjono, 2008) menunjukkan bahwa niat mahasiswa untuk menjadi wirausaha dipengaruhi secara signifikan oleh control perilaku yang dirasakan oleh mahasiswa.

\section{Pengaruh variabel karakteristik pendidikan terhadap intensi berwirausaha}

Hasil analisis menunjukkan bahwa variabel karakteristik pendidikan tidak berpengaruh terhadap intensi berwirausaha. Besarnya pengaruh variabel karakteristik pendidikan terhadap intensi berwirausaha mengacu pada Nilai Standardized Coefficient Beta adalah $-8.76 \%$. pengaruh sebesar $7.38 \%$ tidak signifikan karena nilai signifikansi yang diperoleh $0.1244>0.05$.

\section{KESIMPULAN}

Terdapat pengaruh gabungan yaitu variabilitas intensi berwirausaha yang mampu dijelaskan oleh variabilitas pengaruh sikap, norma subjektif, kontrol perilaku dan karakteristik pendidikan. Hasil menunjukkan bahwa sikap, norma subjektif dan kontrol perilaku secara parsial memiliki pengaruh positif dan signifikan terhadap intensi berwirausaha. Karakteristik pendidikan secara parsial tidak memiliki pengaruh terhadap intensi berwirausaha. Implikasi dari penelitian ini dapat digunakan oleh pihak terkait di Universitas Tidar untuk mengembangkan kebijakan dan program yang dapat meningkatkan intensi berwirausaha mahasiswa Manajemen Universitas Tidar. Program yang dapat 
dipraktikkan oleh pihak Universitas Tidar yaitu mengembangkan pelatihan yang memungkinkan mahasiswa mendapatkan pengalaman wirausaha yang nyata. Pelatihan yang disiapkan harus mengandung unsur standar pelatihan yang dapat meningkatkan tidak hanya pengetahuan dan kemampuan tetapi juga keterampilan.

\section{DAFTAR PUSTAKA}

Ajzen, I. (1991). The Theory of Planned Behavior. Organizational Behavior and Human Decision Processes, 50, 179-211.

Ajzen, I. (2005). Attitudes, Personality and Behavior (2nd ed.). Berkshire, UK: Open University PressMcGraw Hill Education.

Ajzen, I. (2008). Attitudes and Attitudes Change. WD Crano: Psychology Press.

Ajzen, I. (2015). Consumer Attitudes and Behavior: Theory of Planned Behavior Applied To Food Consumption Decisions. Rivista Di Economia Agraria, 121-138.

BPS. (2019). Agustus 2019: Tingkat Pengangguran Terbuka (TPT) sebesar 5,28 Persen. Retrieved January 22, 2020, from 05 November website: https://www.bps.go.id/pressrelease/2019/11/05/1565/agustus-2019--tingkat-pengangguranterbuka--tpt--sebesar-5-28-persen.html

Ciputra, I. (2011). Ciputra Quantum Leap 2. Jakarta: Gramedia.

Ghozali I. (2016). Aplikasi Analisis Multivariate dengan Program IBM SPSS 23 (8th ed.). Semarang: Badan Penerbit Universitas Diponegoro

Gracia, M. J. J. M. (2010). Entrepreneurial Intention: The Role of Gender. International Journal of Entrepreneur Management, 6, 261-283.

Jenkins, M. \& J. G. (1997). Enterpreneurial Intentions and Outcomes: A Comparative Casual Mapping Study. Journal Management Studies, 34, 895-920.

Kotler, P. \& A. G. (2007). Prinsip - Prinsip Pemasaran (12 Jilid I). Jakarta: Erlangga.

Made, N. M. I. M. W. I. P. G. S. (2016). PENGARUH SIKAP, NORMA SUBJEKTIF, DAN PERSEPSI KONTROL KEPERILAKUAN, TERHADAP NIAT SISWA SMK DI KOTA DENPASAR UNTUK MENJADI WIRAUSAHA. Jurnal Ekonomi Dan Bisnis Universitas Udayana.

MRI. (2015). Wirausaha Indonesia Tertinggal Jauh. Retrieved January 22, 2020, from Februari website: http://www.mri-research-ind.com/berita-249-wirausaha-indonesia-tertinggal-jauh.html

Ramayah, T. \& H. Z. (2005). Entrepreneurial Intetion Aming the Student of University Sain Malaysia (USM). International Journal of Management and Entrepreneurship, 1, 8-20.

Saraswati, I. (2018). Pemerintah Targetkan 20.000 Wirausaha Baru. Retrieved January 22, 2020, from 05 Juni website: https://money.kompas.com/read/2018/06/05/083300426/pemerintahtargetkan-20.000-wirausaha-baru

Sarwono, S. W. (2002). Psikologi Sosial Individu dan Teori - Teori Psikologi Sosial. Jakarta: Balai Pustaka.

Sekaran U. (2000). Research Methods for Business: A Skill Building Approach. Third Edition. Singapore: John Wiley and Sons.

Shidiq, M. R. (2019). INTENSI MAHASISWA PERTANIAN BEKERJA SEBAGAI WIRAUSAHA PERTANIAN.

Suharti, L. H. S. (2011). Faktor - Faktor yang Berpengaruh Terhadap Niat Kewirausahaan (Entrepreneurial Intention) Studi Terhadap Mahasiswa Universitas Kristen Setya Wacana. Jurnal Manajemen Dan Kewirausahaan, 13, 124-134.

Teo, T. C. B. L. (2010). Examining The Efficacy of The Theory of Planned Behavior (TPB) to Understand Pre-Service Teachers Intention to Use Technology. In N. T. University (Ed.), Proceeding Ascilite Sydney. Singapore.

Tjahjono, H. K. H. A. (2008). Kajian Niat Mahasiswa Manajemen Universitas Muhammadiyah Yogyakarta Untuk Menjadi Wirausaha. Jurnal Manajemen Dan Bisnis, 16, 46-63.

Wijaya, T. (2008). Studi Meta-Analisis Hubungan Efikasi Diri dan Sikap Toleransi Risiko Dengan Intensi Berwirausaha. Program Doktor Psikologi UGM. 